\title{
Further Evidence of No Association Between Ser9Gly Polymorphism of Dopamine D3 Receptor Gene and Schizophrenia
}

\author{
Chia-Hsiang Chen, ${ }^{1,2^{*}}$ Mei-Ying Liu, ${ }^{6}$ Fu-Chuan Wei, ${ }^{4}$ Farn-Jong Koong, ${ }^{4}$ Hai-Gwo Hwu, ${ }^{5}$ and \\ Kwang-Jen Hsiao ${ }^{3,6}$ \\ ${ }^{1}$ Division of Psychiatry, Cheng Hsin Rehabilitation and Medical Center, Taipei, Taiwan \\ ${ }^{2}$ Division of Neuropsychiatry, School of Medicine, National Yang-Ming University, Taipei, Taiwan \\ ${ }^{3}$ Institute of Genetics, National Yang-Ming University, Taipei, Taiwan \\ ${ }^{4}$ Hung-Chi Psychiatric Hospital, Hsin Tien City, Taiwan \\ ${ }^{5}$ Department of Psychiatry, National Taiwan University, Taipei, Taiwan \\ ${ }^{6}$ Clinical Biochemistry Research Laboratory, Department of Medical Research, Veterans General Hospital-Taipei, \\ Taipei, Taiwan
}

Dopamine D3 receptor (DRD3) was demonstrated to have important implications in schizophrenia, because it binds antipsychotic drugs and is abundant in the limbic system of the brain. Several groups attempted to find an association between a serine-to-glycine polymorphism at codon 9 of the DRD3 gene (Ser9Gly) and schizophrenia; however, the results were inconsistent. We conducted a case-control association study in Han Chinese schizophrenic patients from Taiwan, to examine the relationship of this serine-to-glycine polymorphism and schizophrenia. We noted no significant differences of genotype distribution, allele frequencies, or homozygosity proportion of this polymorphism between schizophrenic patients $(N=178)$ and controls $(N=100)$. When patients were divided according to sex, or presence or absence of family history, the differences were still not significant. Our study does not support the contention that the Ser9Gly polymorphism of the DRD3 gene plays a major role in schizophrenia. Am. J. Med. Genet. 74:40-43, 1997.

๑ 1997 Wiley-Liss, Inc.

KEY WORDS: dopamine; D3 receptor; polymorphism; schizophrenia

\section{INTRODUCTION}

Schizophrenia is a chronic, severe, devastating disease affecting approximately $1 \%$ of the general popu-

*Correspondence to: Dr. Chia-Hsiang Chen, Peitou P.O. Box 2-207, Taipei 11216, Taiwan.

Received 22 February 1996; Revised 28 June 1996 lation. Although family, adoption, and twin studies supported the genetic component of the etiology of schizophrenia, the genes for schizophrenia have not yet been identified, suggesting the complex nature of this disease [Kendler and Diehl, 1993]. Pharmacological studies supporting the involvement of the dopamine pathway in the pathogenesis of schizophrenia come from two lines of evidence. First, currently-used antipsychotic drugs block dopamine receptors [Carlsson, 1988]; second, dopamine receptor-potentiating drugs, such as amphetamines and phencyclidines, accelerate psychotic symptoms of patients [Janowsky and Davis, 1976; Carlsson, 1988]. Hence, dopamine receptors are plausible candidate genes for schizophrenia.

Recent isolation and characterization of a subtype of the dopamine receptor gene, the dopamine D3 receptor (DRD3) gene [Sokoloff et al., 1990], was thought to have important implications in the study of schizophrenia. DRD3 has strong affinity not only to classical antipsychotic drugs, but also to atypical antipsychotic drugs, such as (-)sulpiride, thioridazine, and clozapine [Sokoloff et al., 1990, 1992]. In addition, DRD3 is abundant in the limbic system of the brain [Sokoloff et al., 1990; Bouthenet et al., 1991], an area important for emotion, cognition, and behavior. Furthermore, a recent study reported selective loss of DRD3 and mRNA expression in parietal and motor cortices in patients with chronic schizophrenia [Schmauss et al., 1993], indicating an important role of DRD3 in the pathology of schizophrenia.

The DRD3 gene, which was assigned to 3q13.3 [Le Coniat et al., 1991], contains five exons, and encodes a guanine nucleotide-binding protein-coupled receptor with seven putative transmembrane domains. A polymorphism with A-to-G transition was identified at the first exon of the D3 receptor gene. This A-to-G transition changes a BalI or MscI restriction site, and predicts an amino-acid substitution from serine-to-glycine

(C) 1997 Wiley-Liss, Inc. 
at codon 9 (Ser9Gly), located at the N-terminal extracellular domain of DRD3 [Lannfelt et al., 1992].

Crocq et al. [1992] first reported excessive homozygosity of the BalI polymorphism of the DRD3 gene among schizophrenic patients in British and French Caucasian populations. However, the same result was not found in German patients [Nothen et al., 1993]. Further replication studies did not support the association of the BalI polymorphism of the DRD3 gene and schizophrenia in Swedish Caucasians [Jonsson et al., 1993], in Chinese from mainland China [Yang et al., 1993], and in Japanese [Nanko et al., 1993]. Nevertheless, the relationship between the BalI polymorphism of the DRD3 gene and schizophrenia is still inconclusive, as more studies are performed. Nimgaonkar et al. [1993] reported an association of the BalI polymorphism of the DRD3 gene among patients with positive family history. Mant et al. [1994] also reported that an excess of BalI homozygosity was found in male patients with high familial loading and good neuroleptic treatment response. More recently, another association study in North American patients supported the association between the BalI polymorphism and schizophrenia [Kennedy et al., 1995].

Prompted by the possible involvement of DRD3 in the pathogenesis of schizophrenia, and by the inconsistent results of previous association studies, we set out to examine the relationship between the codon 9 serineto-glycine polymorphism of the DRD3 gene and schizophrenia in a Han Chinese population from Taiwan, by using a case-control association study.

\section{MATERIALS AND METHODS Subjects}

Patients fulfilling the DSM-III-R diagnostic criteria of schizophrenia were recruited from two psychiatric hospitals in Taipei, Taiwan. Clinical symptoms and diagnosis of patients were evaluated by two senior psychiatrists (F.-C.W. and F.-I.K.) with consensus. Family histories were obtained from interviews with caregivers of patients, and from review of medical records. One hundred and seventy-eight unrelated patients were included in this study (95 males and 82 females, mean age 47 years). The controls were unrelated adult nonpsychiatric patients recruited from a community general hospital in the same area as the psychiatric hospitals. The control group consisted of 47 males and 53 females, with mean age of 45 years.

\section{Genotyping}

Genomic DNA was extracted from peripheral blood, using standard methods. The genotyping of Ser9Gly was essentially based on the PCR-based restriction analysis described by Mant et al. [1994], with some modification. After amplification, an aliquot $(10 \mu \mathrm{l})$ of PCR product was incubated with $3 \mathrm{U}$ of $M s c I$ (an isoschizomer of BalI) (New England Biolabs, Inc., Beverly, MA) in a volume of $15 \mu \mathrm{l}$ at $37^{\circ} \mathrm{C}$ overnight. The digested PCR products were subjected to electrophoresis in $3 \%$ agarose gel, then stained with ethidium bromide, and visualized under ultraviolet light. Allele 1 (A1, which encodes serine at codon 9) showed DNA fragments with 130 and $111 \mathrm{bp}$, whereas allele 2 (A2, which encodes glycine at codon 9) showed DNA fragments with 111,98 , and $32 \mathrm{bp}$.

\section{Statistical Analysis}

The genotype frequencies of Ser9Gly polymorphism of schizophrenic patients and controls were examined for fitness of the Hardy-Weinberg equilibrium using the $\chi^{2}$ test. Testing for differences of allele frequencies, genotypes, and homozygosity was performed with the $\chi^{2}$ test. For a two-by-two contingency table, correction for continuity was applied. All statistics were implemented using the Linkage Utilities Programs [Ott, 1991].

\section{RESULTS}

The data on genotype distribution and allele frequencies of patients and controls are shown in Table I. Genotype distributions among patients and controls did not deviate from the Hardy-Weinberg equilibrium $\left(\chi^{2}=\right.$ 0.74 , df $=1, P=0.39$ for schizophrenic patients; $\chi^{2}=$ 0.23 , df $=1, P=0.63$ for controls). There were no significant differences of genotype counts $\left(\chi^{2}=1.02, \mathrm{df}=\right.$ $2, P=0.60)$ or allele frequencies $\left(\chi^{2}=0.10, \mathrm{df}=1, P=\right.$ 0.76 ) between patients and controls. No excess of homozygosity in patients was noted compared with controls $\left(\chi^{2}=0.16, \mathrm{df}=1, P=0.69\right)$. When patients and controls were divided according to sex, still, no differences of genotype distribution $\left(\chi^{2}=0.27, \mathrm{df}=2, P=\right.$ $0.88)$ or allele frequencies $\left(\chi^{2}=0.00, \mathrm{df}=1, P=1.00\right)$ were detected in males. The difference of homozygosity was also not significant between male patients and male controls $\left(\chi^{2}=0.04, \mathrm{df}=1, P=0.85\right)$. Similarly, no significant differences of genotype distribution $\left(\chi^{2}=\right.$ 1.08 , df $=2, P=0.58)$, allele frequencies $\left(\chi^{2}=0.21\right.$,

TABLE I. Genotype Counts and Allele Frequencies of the Ser9Gly Polymorphism of the D3 Receptor Gene Among Schizophrenic Patients and Controls

\begin{tabular}{lccrrrrr}
\hline & \multicolumn{3}{c}{ Genotypes } & & \multicolumn{3}{c}{ Allele frequency } \\
\cline { 2 - 4 } & A1A1 & A1A2 & A2A2 & N & A1 & A2 \\
\hline Schizophrenics & $89(0.50)$ & $77(0.43)$ & $12(0.07)$ & 178 & & 0.72 & 0.28 \\
Male & $44(0.46)$ & $44(0.46)$ & $8(0.08)$ & 96 & & 0.69 & 0.31 \\
Female & $45(0.55)$ & $33(0.40)$ & $4(0.05)$ & 82 & & 0.75 & 0.25 \\
Controls & $50(0.50)$ & $40(0.40)$ & $10(0.10)$ & 100 & & 0.70 & 0.30 \\
Male & $22(0.47)$ & $20(0.43)$ & $5(0.10)$ & 47 & 0.68 & 0.32 \\
Female & $28(0.53)$ & $20(0.38)$ & $5(0.09)$ & 53 & 0.72 & 0.28 \\
\hline
\end{tabular}


TABLE II. Genotype Count and Allele Frequencies of the Ser9Gly Polymorphism of the D3 Receptor Gene Among Schizophrenic Patients With and Without Family History and Controls

\begin{tabular}{lccrrrrr}
\hline & \multicolumn{3}{c}{ Genotype } & & \multicolumn{2}{c}{ Allele frequency } \\
\cline { 2 - 3 } & A1A1 & A1A2 & A2A2 & N & A1 & A2 \\
\hline Schizophrenics & $89(0.50)$ & $77(0.43)$ & $12(0.07)$ & 178 & 0.72 & 0.28 \\
Heredity & $22(0.55)$ & $15(0.38)$ & $3(0.07)$ & 40 & & 0.72 & 0.28 \\
No Heredity & $20(0.35)$ & $31(0.53)$ & $7(0.12)$ & 58 & & 0.62 & 0.38 \\
Unknown & $47(0.59)$ & $31(0.39)$ & $2(0.02)$ & 80 & 0.76 & 0.24 \\
Controls & $50(0.50)$ & $40(0.40)$ & $10(0.10)$ & 100 & 0.70 & 0.30 \\
\hline
\end{tabular}

$\mathrm{df}=1, P=0.65)$, or homozygosity $\left(\chi^{2}=0.01, \mathrm{df}=1, P=\right.$ 0.91 ) were detected between female patients and female controls. When patients were grouped according to presence or absence of family history, 40 patients were found to have positive family history, whereas 58 patients did not have positive family history, and 80 patients, who could not be confirmed due to insufficient information, were categorized as "unknown." The data on genotype counts and allele frequencies of these subgroups are listed in Table II. No differences of genotype distribution $\left(\chi^{2}=0.38, \mathrm{df}=2, P=0.83\right)$ allele frequencies $\left(\chi^{2}=\right.$ 0.23 , df $=1, P=0.63)$, or homozygosity $\left(\chi^{2}=0.01\right.$, $\mathrm{df}=$ $1, P=0.93)$ were detected between patients with positive family history and controls. When patients with positive family history were compared with patients without family history, similarly, the differences of genotype counts $\left(\chi^{2}=4.09, \mathrm{df}=2, P=0.13\right)$, allele frequencies $\left(\chi^{2}=2.80, \mathrm{df}=1, P=0.09\right)$, or homozygosity $\left(\chi^{2}=1.82, \mathrm{df}=1, P=0.18\right)$ were not significant.

\section{DISCUSSION}

In this communication, we reported no association of the Ser9Gly polymorphism of the human DRD3 gene and schizophrenia in a Han Chinese population from Taiwan. Our data are consistent with the results reported by Yang et al. [1993], who also found no association between the Ser9Gly polymorphism of the DRD3 gene and schizophrenia in Han Chinese from Sichuan province of western mainland China. It is notable that the allele frequencies and genotype frequencies of both patients and controls from these two studies are almost the same (as summarized in Table III), indicating high homogeneity of the Ser9Gly polymorphism of the DRD3 gene in both studies. In consideration of populationbased case-control association design, population stratification or sampling bias is an important confounding factor that leads to false-positive results [Kidd, 1993]. The highly homogeneous ethnic background and close fit of genotype frequencies to the Hardy-Weinberg equilibrium reduce the possible error due to population stratification in the present study. When we divided patients and controls into subgroups by sex or family history, still no association was observed in our study, which is also in agreement with results from Yang et al. [1993]. We did not subgroup patients according to neuroleptic responses in the present study, because our patients are recruited from two long-stay mental hospitals, and in fact, most of the patients are poor responders to neuroleptic treatment.

Another important strategy to test claimed association is to increase sample size, and to conduct replication study by independent groups. The present study, which is independent from that of Yang et al. [1993] using a Chinese population, has a large sample size of patients $(\mathrm{N}=178)$ and controls $(\mathrm{N}=100)$, to offer enough power to detect association if present. Thus, our study provides further evidence of lack of association between the Ser9Gly polymorphism of the DRD3 gene and schizophrenia.

The results of the present study are also in line with another study using family-based association design. Macciardi et al. [1994] used haplotype relative risk (HRR) design to examine the relationship of Ser9Gly polymorphism and schizophrenia in an Italian population, and no association was detected. HRR uses parental nontransmitted alleles as controls, and pre-

TABLE III. Genotype Count and Allele Frequencies of the Ser9Gly Polymorphism of the D3 Receptor Gene Among Schizophrenic Patients and Controls From Taiwan and Mainland China

\begin{tabular}{|c|c|c|c|c|c|c|}
\hline & \multicolumn{3}{|c|}{ Genotypes } & \multirow[b]{2}{*}{$\mathrm{N}$} & \multicolumn{2}{|c|}{$\begin{array}{c}\text { Allele } \\
\text { frequency }\end{array}$} \\
\hline & A1A1 & $\mathrm{A} 1 \mathrm{~A} 2$ & $\mathrm{~A} 2 \mathrm{~A} 2$ & & A1 & $\mathrm{A} 2$ \\
\hline $\begin{array}{l}\text { Schizophrenics, } \\
\text { Taiwan }\end{array}$ & $89(0.50)$ & $77(0.43)$ & $12(0.07)$ & 178 & 0.72 & 0.28 \\
\hline $\begin{array}{l}\text { Schizophrenics, } \\
\text { mainland China }\end{array}$ & $54(0.51)$ & $45(0.42)$ & $8(0.07)$ & 107 & 0.71 & 0.29 \\
\hline Controls, Taiwan & $50(0.50)$ & $40(0.40)$ & $10(0.10)$ & 100 & 0.70 & 0.30 \\
\hline $\begin{array}{l}\text { Controls, } \\
\text { mainland China }\end{array}$ & $50(0.51)$ & $40(0.41)$ & $8(0.08)$ & 98 & 0.71 & 0.29 \\
\hline
\end{tabular}


vents the error of population stratification [Falk and Rubinstein, 1987]. In addition, several linkage studies did not find close linkage of the DRD3 gene locus and schizophrenia [Wiese et al., 1993; Nanko et al., 1994; Sabate et al., 1994]. Hence, taking together the results of linkage and association studies, the DRD3 gene locus may not play an important role in schizophrenia genetics.

Despite the negative results of association and linkage studies, the possible physiological role of the DRD3 gene in the pathogenesis of schizophrenia cannot be ruled out. A recent study revealed selective loss of DRD3 mRNA expression in the motor, primary somatosensory, and somatosensory areas of cortices from postmortem brains of chronic schizophrenic patients, which cannot be explained by age of patients or treatment with neuroleptics [Schmauss et al., 1993]. Although the results need to be confirmed by further studies, this study implicates another possibility, that molecular defects in other genes that regulate the expression of the DRD3 gene could be involved in the pathogenesis of schizophrenia.

\section{REFERENCES}

Bouthenet M-L, Souil E, Martres M-P, Sokoloff P, Giros B, Schwartz J-C (1991): Localization of dopamine D3 receptor mRNA in the rat brain using in situ hybridization histochemistry: Comparison with dopamine D2 receptor mRNA. Brain Res 564:203-219.

Carlsson A (1988): The current status of the dopamine hypothesis of schizophrenia. Neuropsychopharmacology 1:179-186.

Crocq M-A, Mant R, Asherson P, Williams J, Hode Y, Mayerova A, Collier D, Lannfelt L, Sokoloff P, Schwartz J-C, Gill M, Macher JP, McGuffin P, Owen MJ (1992): Association between schizophrenia and homozygosity at the dopamine D3 receptor gene. J Med Genet 29:858-860.

Falk CT, Rubinstein P (1987): Haplotype relative risk: An easy, reliable way to construct a proper control sample for risk calculations. Ann Hum Genet 51:227-233.

Janowsky DA, Davis JM (1976): Methylphenidate, dextroamphetamine, and levamphetamine: Effects on schizophrenic symptoms. Arch Gen Psychiatry 33:304-308.

Jonsson E, Lannfelt L, Sokoloff P, Schwartz J-C, Sedvall G (1993): Lack of association between schizophrenia and alleles in the dopamine D3 receptor gene. Acta Psychiatr Scand 87:345-349.

Kendler KS, Diehl SR (1993): The genetics of schizophrenia: A current, genetic-epidemiologic perspective. Schizophr Bull 19: 261-285.

Kennedy JL, Billett EA, Macciardi FM, Verga M, Parsons TJ, Meltzer HY, Lieberman J, Buchanan JA (1995): Association study of dopamine D3 receptor gene and schizophrenia. Am J Med Genet $60: 558-562$.
Kidd KK (1993): Association of disease with genetic markers: Déjà vu all over again. Am J Med Genet 48:71-73.

Lannfelt T, Sokoloff P, Martres M-P, Pilon C, Giros B, Jonsson E, Sedvall G, Schwartz J-C (1992): Amino acid substitution in the dopamine D3 receptor as useful polymorphism for investigating psychiatric disorders. Psychiatr Genet 2:249-256.

Le Coniat M, Sokoloff P, Hillion J, Martres MP, Giros B, Pilon C, Schwartz JC, Berger R (1991): Chromosomal localization of the human D3 dopamine receptor gene. Hum Genet 87:618-620.

Macciardi F, Verga M, Kennedy JL, Petronis A, Bersani G, Pancheri P, Smeraldi E (1994): An association study between schizophrenia and the dopamine receptor genes DRD3 and DRD4 using haplotype relative risk. Hum Hered 44:328-336.

Mant R, Williams J, Asherson P, Parfitt E, McGuffin P, Owen MJ (1994): Relationship between homozygosity at the dopamine D3 receptor gene and schizophrenia. Am J Med Genet 54:21-26.

Nanko S, Sasaki T, Fukuda R, Hattori M, Dai XY, Kazamatsuri H, Kuwata S, Juji T, Gill M (1993): A study of the association between schizophrenia and the dopamine D3 receptor gene. Hum Genet 92:336-338.

Nanko S, Fukuda R, Hattori M, Sasaki T, Dai XY, Yamaguchi K, Kazamatsuri H (1994): Further evidence of no linkage between schizophrenia and the dopamine D3 receptor gene locus. Am J Med Genet 54:264-267.

Nimgaonkar VL, Zhang XR, Caldwell JG, Ganguli R, Chakravarti A (1993): Association study of schizophrenia with dopamine D3 receptor gene polymorphisms: Probable effects of family history of schizophrenia? Am J Med Genet 48:214-217.

Nothen MM, Cichon S, Propping P, Fimmers R, Schwab SG, Wildenauer DB (1993): Excess of homozygosity at the dopamine D3 receptor gene in schizophrenia not confirmed. J Med Genet 30:708-712.

Ott J (1991): "Analysis of Human Genetic Linkage, Revised Edition.” Baltimore: Johns Hopkins University Press, pp 165-193.

Sabate O, Campion D, d'Amato T, Martres MP, Sokoloff P, Giros B, Leboyer M, Jay M, Guedj F, Thibaut F, Dollfus S, Preterre P, Petit M, Babron M-C, Waksman G, Mallet J, Schwartz J-C (1994): Failure to find evidence for linkage or association between the dopamine D3 receptor gene and schizophrenia. Am J Psychiatry 151:107-111.

Schmauss C, Haroutunian V, Davis KL, Davidson M (1993): Selective loss of dopamine D3-type receptor mRNA expression in parietal and motor cortices of patients with chronic schizophrenia. Proc Natl Acad Sci USA 90:8942-8946.

Sokoloff P, Giros B, Martres M-P, Bouthenet M-L, Schwartz J-C (1990): Molecular cloning and characterization of a novel dopamine receptor (D3) as a target for neuroleptics. Nature 347: $146-151$.

Sokoloff P, Martres M-P, Giros B, Bouthenet M-L, Schwartz J-C (1992): The third dopamine receptor (D3) as a novel target for antipsychotics. Biochem Pharmacol 43:659-666.

Wiese C, Lannfelt L, Kristbjarnarson H, Yang L, Zoega T, Sokoloff P, Ivarsson O, Schwartz J-C, Moises HW, Helgason T (1993): No evidence of linkage between schizophrenia and D3 dopamine receptor gene locus in Icelandic pedigrees. Psychiatry Res 46:69-78.

Yang L, Li T, Wiese C, Lannfelt L, Sokoloff P, Xu CT, Zeng Z, Schwartz J-C, Liu X, Moises HW (1993): No association between schizophrenia and homozygosity at the D3 dopamine receptor gene. Am J Med Genet 48:83-86. 